In addition to granting degrees the Council is em. powered by its Charter to grant diplomas and certificates comparable with those awarded by universities. The Council will consider the ways in which this power shall be exercised.

The Council believes that it will need to offer higher degrees both at master and doctor level. However, some time may elapse before the Council can make a firm statement on this point, since it must obviously give first priority to the establishment of its first degrees.

The Council will ensure continuity of the award of membership of the College of Technologists by taking over this work from the National Council for Technological
Awards as soon as this can be arranged, and details will be announced in the very near future. As part of the longterm consideration of the higher degrees it will offer, the Council will consider whether in due course one of its own higher degrees shall be granted for programmes of work of the type which now lead to the award of membership of the College of Technologists. If any changes are made these will apply also to the holders of the award and to students working for it.

Further information, including fees, etc., can be obtained from the registrar and secretary, Mr. F. R. Hornby, Council for National Academic Awards, 24 Park Crescent, London, W.1.

\title{
THE SPARTINA STORY
}

$\mathrm{T}$ O-DAY, even the layman is often aware that a vigorous new maritime grass has become increasingly widespread around the coasts of Britain, and now forms conspicuous swards on many tidal flats. It is less commonly realized, however, that this large and aggressive newcomer, of the genus Spartina, was completely unknown a century ago. Under the title of "The Spartina Story", current work concerning its origin, present ecological status and economic value was brought together at a meeting of Section K (Botany) of the British Association for the Advancement of Science on August 26 at Southampton; since the grass originated on the shores of Southampton Water, the location of the symposium was particularly apt.

The symposium was introduced and chaired by Dr. C. E. Hubbard (deputy director of the Royal Botanic Gardens and keeper of the Herbarium at the Royal Botanical Gardens, Kew), who discussed the general taxonomy and distribution of the grass; Dr. C. J. Marchant (also of Kew and formerly of the University of Southampton) considered its origin in the light of recent cytological investigations; Dr. J. M. Lambert and Prof. W. T. Williams (both of the University of Southampton) dealt respectively with ecological work on the grass and with possible physiological causes of the incidence of 'die-back' in some swards; and Dr. D. S. Ranwell (Nature Conservancy) summarized the broader aspects of the establishment of Spartina, with particular reference to its use for economic purposes and its general significance to man.

The story formally begins with the recognition and description of the grass as a new species, under the name of Spartina townsendi (later townsendii), by the brothers $H$. and J. Groves, from material collected near Hythe in 1878. Investigations have since revealed that previous collections were made in 1870 and possibly even before, and that the early material (including the type specimen) consisted of sterile plants. Later collections, however, were principally of a more robust, fertile grass, and--pending taxonomic revision-the name Spartina townsendii is commonly still used indiscriminately to cover both sterile and fertile material.

From the time of its first discovery as a hitherto unknown British plant, there has been much speculation concerning the origin of the grass. Suggestions included accidental introduction from the United States, mutation of an existing species, and hybridization. The last possibility was made particularly plausible by the fact that the new Spartina was morphologically intermediate between two other species which existed together in the locality at the time, namely $S$. maritima, native to Britain, and $S$. alterniflora, a North American species believed to have been introduced accidentally by shipping into the Southampton area in the early nineteenth century.

In 1931 , C. L. Huskins published an investigation of hereditary relationships in 'British' representatives of Spartina from eytological findings. Unaware of the existence of the sterile plant, he gave the chromosome complement of fertile $S$. townsendii as $2 n=126$, and derived it by chromosome doubling from a hypothetical 63-chromosome hybrid between S. maritima $(2 n=56)$ and $S$. alterniflora $(2 n=70)$. Unfortunately, Huskins's results were thrown open to doubt by the fact that, believing $S$. alterniflora to have become extinct in its former British locality, he made his counts for this poly. morphic species on American material; moreover, the cytological techniques available at that time were inadequate for examining the small chromosomes of Spartina with any degree of precision.

In his recent re-investigation of the situation, C. J. Marchant was not only able to use modern techniques, but also to find and examine British material of S. alterniflora still surviving in the Southampton Water area. Both sterile and fertile plants of $S$. townsendii were included in his investigations, and chromosome counts from a wide range of material gave the following numbers: S. maritima 60 (never 56); S. alterniflora 62 (never 70); sterile S. townsendii 62 ; fertile $S$. townsendii variable with 120 , 122 (commonest) and 124. Although the new counts provided a numerically less-exact scheme of relationships than that suggested by Huskins, the postulated origin of fertile $S$. townsendii by hybridization and subsequent chromosome dnubling was nevertheless supported. The hybrid nature of the sterile plant was attested by irregularities in chromosome pairing at meiosis, while careful comparison of chromosome morphology confirmed its derivation from $S$. maritima and $S$. alterniflora; in contrast, the 120- to 124-chromosome form of $S$. townsendii showed almost regular pairing, while the discovery of other Spartina plants, intermediate in external form and chromosome number (90 and 76), suggested back-cross links between $S$. townsendii and S. alterniflora.

Because of the interest aroused by the first appearance of $S$. townsendii, the subsequent spread of the grass has been recorded by botanists in detail. Much of its early spread from its original station near Hythe was by natural means, and by 1915 it was established in every south-coast estuary from Chichester to Poole. From the early 1920's onwards its range was greatly extended by artificial plantings, and it now covers at least 30,000 acres of tidal flats around the British Isles alone.

The story of Spartina in Britain, however, is not solely one of uninterrupted success in the occupation of new habitats. Within the past 40 years there have been a number of reports of patchy degeneration-'die-back' - of previously healthy Spartina swards. This problem was recently investigated by $\mathrm{P}$. J. Goodman and Mrs. E. M. Braybrooks at the University of Southampton. Their detailed surveys showed that the pattern of die-back seemed remarkably constant in affected areas, with 'channel die-back' along the edges of the major creeks, 'pan die-back' in low-lying areas in the middle of marsh segments, and healthy Spartina on slightly raised banks 
or levées nearer the creeks. There was no evidence to associate the incidence of die-back with pollution or pathogen attack; indeed, both field observations and transplant experiments suggested strongly that die-back resulted from the establishment of locally unfavourable habitat conditions.

The reason for die-back pan formation in previously healthy swards was elucidated by means of soil borings. In a number of different sites, levelled lines of bores showed that a decrease had occurred in the general slope of the marsh from back to front following colonization by Spartina; the grass had caused greater mud accretion at the front, and drainage of the marsh surface had been progressively impaired. Similarly, bores across marsh segments lying between adjacent creeks gave evidence of a change from a convex to a concave profile for the intervening marsh, resulting in more or less permanently waterlogged conditions in the centres of the segments. The appearance of die-back pans thus resulted from the normal physiographical development of the sward: levees had been produced by mud filtered from the tidal water by the Spartina plants themselves, and surface run-off from the marsh had thereby been locally impeded. The cause of channel die-back was less certain; but it may have been due to the slipping of soft mud back into the channels, bringing the neighbouring marsh surface down to a level ton constantly flooded for healthy Spartina growth.

Although the field evidence strongly suggested an ecological connexion between Spartina die-back and exces. sive wetness of the soil, the physiological explanation of such die-back was by no means clear. Symptoms of dieback included death of underground buds and soft-rotting of the rhizome apices, but such symptoms could be due to a number of causes. The deleterious effect of waterlogging on plants is commonly attributed to lack of oxygen in the soil; but this again could operate in several different ways--by causing toxic substances like alcohol or acetal. dehyde to accumulate in the tissues as a result of anaerobic respiration, by interfering with some important vital process, by producing poisonous substances like ferrous salts, sulphides or nitrites in the soil, or by predisposing the plant to bacterial or fungal attack by any of these mechanisms.

Laboratory experiments, carried out at Southampton by P. J. Goodman, Miss S. Barker and A. Ivemy, and discussed by Prof. Williams, have now reduced these possibilities to that of interference with some vital but unidentified function in the plant. Alcohol-and acetaldehyde-levels in die-back plants were too low to be critical for growth; the presence of bacteria in Spartina rhizomes was not consistently associated with die-back; and, although high concentrations of sulphide were present in die-back soils, no quantitative relationship could be established with rhizome apices cultures at different sulphide-lovels, while, on the other hand, die-back symptoms could be produced in the absence of sulphide when oxygen was excluded from the cultures. It is certainly possible that soil sulphides are indirectly responsible for die-back by forming an oxygen sink, but the basic physiological effect of lack of oxygen still remains essentially unresolved.

Whatever may be the ultimate cause of die-back in Spartina, once it is initiated in a sward the weakened areas may be enlarged by tidal scour so that the sward becomes progressively disintegrated. At present, the phenomenon of die-back is very restricted in extent, and limited to marshes on fine-textured soils with exceptionally poor subsoil drainage. In other Spartina areas with coarser soils it is probable that more stable conditions will result; most swards are still too young for their ultimate fate to be predicted with any cortainty.

Although Spartina seems susceptible to continuous water-logging, it nevertheless appears more tolerant of wet conditions than many other salt-marsh plants. It thus tended in the first place to colonize bare mud flats in front of existing salt-marshes, and this type of situation is sometimes regarded as its exclusive habitat. However, there is increasing evidence that it is now also migrating backwards into older saltings and ousting the original salt-marsh vegetation.

One such investigation of the successful invasion of preexisting saltings was carried out by Miss Barker at Southampton, with particular reference to the mechanism by which Spartina replaces Juncus maritimus, a tall-growing species which normally occupies the higher and drier salt-marsh zones. A number of soil borings made in critical sites established that the entry of Spartina had greatly accelerated the rate of mud deposition where it had invaded, so that, whereas the high-lying Juncus zone had previously been freely drained, it was now thickly flanked by recently accumulated mud. Morphological and anatomical investigations of plants from the disappearing Juncus zone suggested that Juncus was showing the same die-back symptoms as were exhibited by Spartina under more extreme conditions; its replacement by Spartina, therefore, appeared to hinge on its greater susceptibility to impeded drainage rather than on a more direct competitive effect.

The power of rapid mud accretion by Spartina has long been recognized as one of its outstanding characteristics as a salt-marsh plant. In fact, its potential value for stabilizing and reclaiming inter-tidal flats was realized as early as the beginning of this century, and many thousands of cuttings and seeds have since been distributed to various parts of Britain and to more than 40 countries in different parts of the world. Dr. D. S. Ranwell and his colleagues in the Nature Conservancy have recently collected much information on the distribution and use of Spartina for economic purposes, and their survey indicates that $S$. townsendii now covers a world total of some 70 square miles or more.

Outside the British Isles, the establishment of S. town. sendii has been most successful in the Netherlands, France and Germany. Its present known geographical limits are between $48^{\circ}$ and $58^{\circ} \mathrm{N}$. on European coasts. It has also been introduced successfully at $48^{\circ} \mathrm{N}$. on the western seaboard of the United States, but plantings have failed at $45^{\circ} \mathrm{N}$. on the colder eastern side. In Australia and New Zealand it survives between $35^{\circ}$ and $46^{\circ} \mathrm{S}$. Where otherwise suitable habitats exist, it seems to be restricted by frost damage on the polar sides of these limits. On the equatorial side, it apparently succeeded for a few years on the coast of British Guiana only $7^{\circ} \mathrm{N}$. of the equator, but was finally smothered in competition with the native species S. brasiliensis; so far as is known, it has not survived in any other tropical sites.

In Britain itself, the primary use of Spartina has been for coast protection. A very successful example of this is seen at Bridgwater Bay on the Somerset coast, where a 2.5-mile length of the coastline has been effectively protected and the foreshore-level raised by $5 \mathrm{ft}$. since Sfartina was planted in 1929. A similar use has been made of the grass in the Mitchell estuary and around the Gippsland lakes in Australia, and in the South Island of New Zealand.

In the Netherlands, Denmark and Germany, and also on a smaller scale in Britain round the Wash, Spartina has been used mainly for reclamation purposes. Perhaps the biggest and most successful reclamation experiment was that carried out in the Sloe Dam area in Holland, where large-scale planting started in 1925; by 1949 the first Spartina polder was ripe for reclamation, and the whole area is now a settled agricultural district. In northern Holland, planting of Spartina was at first less successful, and all but about 1 per cent of the initial transplants from south Holland were killed by winter frosts; with later selection and propagation of winter-hardy forms, how ever, there are now extensive Spartina meadows along the Groningen coast.

It was Prof. F. W. Oliver, one of the pioneer investigators of Spartina in Britain, who realized that the new 
British grass had potentialities not only for reclamation but also as a crop. Its food value to stock is roughly equivalent to that of medium-quality hay, and it seems to be relished by a wide variety of herbivores. Although it has proved too coarse for the highly bred livestock of countries like Holland and Denmark, the older breeds of domestic animals grazo freely on Spartina when it is available. Because of the difficult terrain on which it grows, there have been few attempts actually to harvest the grass. However, an experiment at Bridgwater Bay has shown that in suitable areas it is possible to cut and transport Spartina using light machinery, and the cut material is being tosted for possible use as silage.

In spite of its economic value, the advent of Spartina is not an unmixed blessing. The very rapidity with which it can spread and transform a habitat can itself be a cause of trouble in certain circumstances. Fears that it would block major navigation channels in harbours have proved unfounded; but in estuarino marshes it sometimes chokes minor channels used by yachtsmen. Again, where it invades mud-flats near holiday beaches, the arnenities of the area may be spoiled, and the beaches themsolves eventually obliterated. Further, from a conservation angle, there is a very real danger that certain forms of wild-life may be lost in coastal areas overrun by the grass; othor salt-marsh plants may be eliminated, the feeding grounds for wintering wild-fowl covered, and variety in the marshes reduced at the expense of the spread of a single species. Control measures for Spartina are under investigation, however, and some success has been achieved with carefully timed applications of some of the more innocuous herbicides.

In all, the Spartina townsendii story is clearly one of importance from both an academic and a practical point of view. Its main scientific interest lies in its exemplification of the evolution of a now species under natural conditions by hybridization between two geographically isolated specios brought together by chance, restoration of fertility by chromosome doubling, and successful establishment in a vacant ecological niche. Man has not been slow to take advantage of the particular ecological and physiological properties of the new species which have contributed to its success; and it is perhaps ironic to note that it is just these marsh-building properties which may have hastened reclamation and industrial development along the Southampton Water shores, so that the classic birthplace of Spartina townsendii is now threatened with extinction.

J. M. LAMBERT

\section{NEWS and VIEWS}

\section{Genetics in the University of Birmingham:}

Prof. J. L. Jinks

DR. J. I. JINks, at prosent honorary reador in genetics in the University of Birmingham, has been appointed to the chair of gonetics in succession to Prof. K. Mather, who has been appointed Vie(-Chancellor of the University of Southampton (Nature, 203, 24; 1964). Dr. Jinks gained both his B.Sc. and his Ph.D. at tho University of Birmingham. Ho graduated in botany in 1950 and was awarded a resoarch studentship in genetics by the Agricultural Rosoarch Council, which he held in the Departmont of Genctics in the Univorsity, obtaining his Ph.D. in 1952. Following his resoarch studentship, ho was appointed to the staff of the Agricultural Rosearch Council's Unit of Biomotrical (Kenetics, attached to the Dopartment of Genetics, and has continued in this appointment up to the present time. He spent a year as a Harkness Fellow at the California Institute of Tochnology, and has worked for shorter poriods in Coponhagen and Milan. Dr. Jinks's research has been mainly concerned with inheritanco in moulds, bactoria and viruses, how they adjust themselves to their onvironments and how those which cause diseasos of domestic plants adapt thernselves to attack their hosts. Ho has also investignted the inheritance of characters which, like yiold in domestic plants and animals, vary by imperceptible gradations over a wide range of phenotypic expressions. The mothods of analysis that ho has dovised for such characters are now in wide use by plant breodors and have also lod to important advanees in the understanding of the horeditary determination of bohaviour in animals. Dr. Jinks's appointment will tako offoct from ()ctobor 1, 1965.

\section{Agricultural Chemistry in the University of Leeds:} Prof. J. A. F. Rook

DR. J. A. F. Rook, principal scientific officer in the Chomistry Dopartment of the National Institute for Resoarch in Dairying. Shinfield, has been appointed to the chair of agricultural chemistry in the University of Loeds. Dr. Rook was oducated at Scarborough High School for Boys and the University College of Wales, where he graduated with first-class honours in chemistry with agricultural chernistry in 1947. Ho held an Agricultural Resoarch Council research training grant from 1947 until 1950 and spent two yoars in the Chemistry and Physies
Department of the National Instituto for Rosearch in Dairying, followed by one year in the Department of Animal Physiology and Biochemistry of tho Danish State Agricultural Research Laboratorics, Copenhagen. $\mathrm{He}_{e}$ gained a Ph.D. degree at the University of Glasgow in 1957 for a thesis on "Some Studies on Fnergy Metabolism". In 1950 he was appointed scientific officer at the Hannah Dairy Research Institute, Ayr, and three years later was promoted to senior scientific officer. $\mathrm{He}$ returned to the National Institute for Resenrch in Dairying in 1954, as senior scientific officer, and has hold his present appointmont as principal scientific officer in the Chemistry Department of that establishment since 1961. Dr. 1Rook's research interests include magnesium metabolism in calves and dairy cows, milk composition and metabolism and milk secretion.

\section{Applied Mathematics in the University of Liverpool:} Prof. J. G. Oldroyd

Prof. J. G. Ol.droyd, professor of applied mathomatics in the University College of Swansea, has beon appointed to the newly established socond chair of applicd mathomatics in the University of Liverpool. Prof. Oldroyd is forty-threo yoars of ago and was educated at Bradford Grammar School and Trinity College, Cambridgo, where he won the Rouse Ball Mathematical Prize in 1941, the Mathison Prize in 1942, and sucenssfully completed the Cambridge Mathematical 'Tripos Part III with distinction in 1942; he was awarded a B.A. degree in 1942, M.A. in 1946, Ph.D. in 1949 and Sc.D. in 1958. From 1942 until 1945 he served as an experimontal offieer with the Ministry of Supply, undertaking theoretical resoarch mainly on the internal ballisties of rockets. From 1945 until 1953 he held tho post of mathomatical physicist at Courtaulds' Fundamental Resoarch Laboratory at Maidenhoad. He was a Fellow of Trinity Collego, Cambridge, from 1947 until 1951. In 1953 he was appointed professor of applied mathematics at University College of Swansea and became hoad of the Department of Applied Mathematics when it was created in 1957. Prof. Oldroyd has served as Dean of the Faculty of Science at Swansea, as a member of the College Council, a member of the Academic Board of the University of Wales and a member of tho University of Wales Commission. From 1955 until 1957 ho was president of the British Society of Rheology. Prof. Oldroyd will take up his new appointment on January 1. 